\title{
EXPERIMENTAL STUDY OF THE VARIATION DYNAMIC'S FOR AIR HEAT EXCHANGER
}

\author{
Maryia MAROZAVA ${ }^{1}$, Dzmitry HRYNIUK ${ }^{2}$ \\ Belarusian State Technological University, Minsk, Belarus

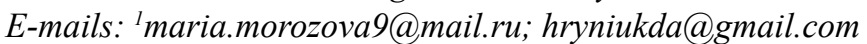

\begin{abstract}
The development of management systems is assigned one of the leading roles. When solving the problems of regulating the technological parameters, various problems arise. One of such problems is the adjustment of control loops. For some control objects, one-time adjustment of the controller parameters can be made, and then it is periodically refined as necessary. In other objects, the changes occur very quickly, but in a certain range. In the latter case, you should first estimate the range of changes. Then find universal robust settings that will ensure the stability and quality of the stabilization system. Some of such objects are air heat exchangers. The article presents the results of the determination of the heat exchanger dynamics. The limits of the variation of the parameters of the dynamic models are determined. There is a significant nonlinearity in the transfer function of the control channel.
\end{abstract}

Keywords: heat exchanger, model, active experiment.

\section{Introduction}

Process of automation has become a prerequisite for modern industrial enterprises. The period of extensive ways of increasing the level of automation through the installation of measuring devices with the necessary precision and tuning of local loops is almost over. Currently, it is not enough just to set up a proportional-integral-derivative controller. Obtaining competitive advantage requires the use of more sophisticated algorithms, adaptation of local loops under the influence of the changing contours and optimization in real time. In modern literature, there was a special term: Advanced Process Control (APC) (Emerson Process Management 2016).

It is known from control theory that the system settings for optimal transition process are differences in the perturbation and the reference signal. However, due to the complexity of prediction situations in the facility management equipment installers set common settings. At sites where there is are mutual influence of individual control loops, control settings are selected with an even greater margin of stability to ensure the robustness of working circuits.

However, solutions from large companies are expensive to use in small businesses. In most of the existing control, loops are "soft" control settings. They include the introduction of excessive margin sustainability, and provide poor quality control. Sometimes you can see a good quality setting loop. This happens because of the availability in the technical means of automation built-in auto-tuning mode.

Auto-tuning control loops has its restrictions on the application. Using this mode can lead to tragic consequences, when an object is a wide range of changes in its dynamic properties and / or speed of these changes. In this case it is possible to study the variation of the dynamic parameters of the object and find robust setup or use a table lookup. Robust settings suggest stability and good quality control for different variations of dynamic and static properties of the object. The table management provides a deeper study of the object, finding the causes of changes in dynamics and deterministic modification of the control loop settings depending on the situation.

\section{Control object}

One of such objects, where robust configuration and table management may be applied, is stabilization of temperature in conditioning systems. Air flow rate can vary over a wide range. The air that passes through the heating or cooling system is rarely constant temperature and humidity throughout the day. A large number of metal pieces of equipment and ducts leads to a large inertia.

It is possible to study and develop the methodology of the loop on the bottom of such objects on the basis of the laboratory stand. 
It is possible to study and develop the methodology for tuning the control loop at one of these facilities on the basis of a laboratory bench.

In order to identify the properties of objects, a series of experiments served as the basis for the controller VIPA 200. It belongs to the series of medium-sized PLC, it can implement PID control algorithm and digital filtering. Performance, memory capacity and functionality of these controllers are on a par with systems such as the Simatic S7-300, Modicon TSX Micro, OMRON CJ1, MELSEC AnAS. Time of the operation with bits $-0.25 \mathrm{~ms}$, with the words $-1.2 \mathrm{~ms}$. Memory size: $48 \mathrm{kB}$ work memory, $80 \mathrm{kB}$ load memory (VIPA products 2016).

The controller is connected to the equipment with the thermal heaters where the blowing air flow. The flow rate was regulated by changing the speed of the fan motor (Fig. 1). Air informative parameters used air temperature at the inlet and outlet, the information about the frequency of the drive directly and through a secondary converter were used as informative parameters. Each of these information channels has its own characteristic associated with the source and method of entering into the input register controller in the form of digital data.

Two heaters have a power of 600 watts. The total length of the pipe between the first heater and the output temperature sensor is about 2.5 meters. The pipe have size about 200 to 200 millimeters. Electric motor is 540 watts. Omron frequency inverter series CIMR-J7.

The output temperature sensor connected to the controller without the using of a standardized conversion signal. We used the direct conversion of Pt100 resistance (Endress + Hauser) to the universal module for programmable logic controller three-wire scheme. This eliminated the error of the secondary instrument from the measurement channel, but led to the problem of a large value of the least significant digit. This ADC module has 10 bits per degree (as per specification). But in reality only the module gave values of about 3-4 degrees Celsius. A typical trend can be

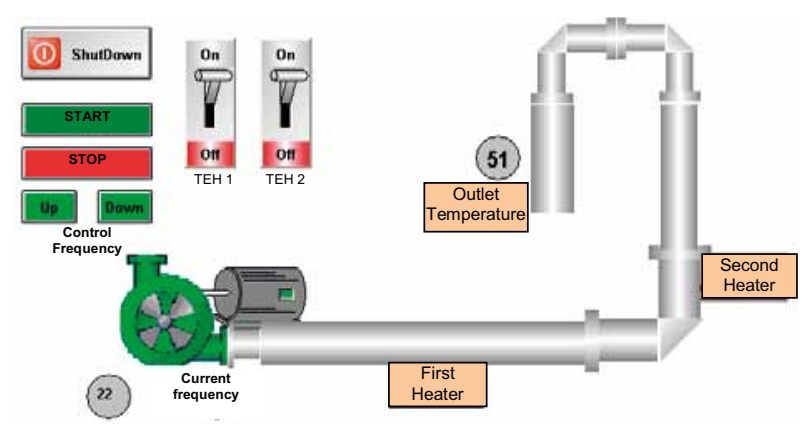

Fig. 1. Screen shot SCADA - InduSoft Web Studio v6.1

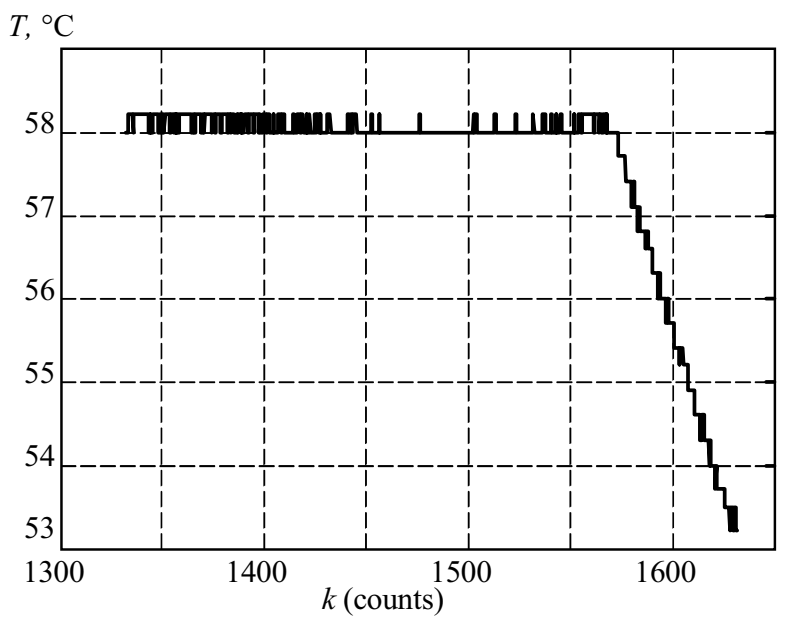

Fig. 2. Trend value changes in the input register controller

seen in Fig. 2. The use in the circuits of control data values is only possible by using a smoothing filter.

From a practical point of view, the best use of a filter a running average or a digital low-pass filter. A digital filtering algorithm with time constant $T_{f}$ in the controller assumes the implementation of a simple Euler scheme (Olson, Piani 2001).

$$
y\left(k T_{i}\right)=\alpha y\left[(k-1) T_{i}\right]-(1-\alpha) x\left(k T_{i}\right),
$$

where $y\left(k T_{i}\right), y\left[(k-1) T_{i}\right]$ - the filter output value in the current and the previous count respectively; $x\left(k T_{i}\right)$ - the value of the input register PLC; $T_{i}$ - the simple time; $k$-current number count.

$$
\alpha=\frac{T_{f}}{T_{f}+T_{i}} .
$$

This aspect and feature should be considered when selecting a control system configuration. Using the filter increases the inertia of the measuring channel. To improve performance, you can abandon the smoothing measurement information. In this case it is necessary to eliminate not only the differential-differential component of the controller, but to impose restrictions on the amount of the gain. As an actuator in the control loop, a frequency drive is used. It has low inertia and will not dampen the performance of the reference signal. Any significant noise in the measurement path will lead through the gain controller to the rapid changes in control action.

\section{Communication interface setting}

Control and recording data which were carried out using MatLab data sharing structure are shown at Fig. 3. The data occurred with a frequency of $0.1 \mathrm{~Hz}$. The experiment was conducted in a single day. The next step was the separation of the data into separate steps to change the set point (SP). 


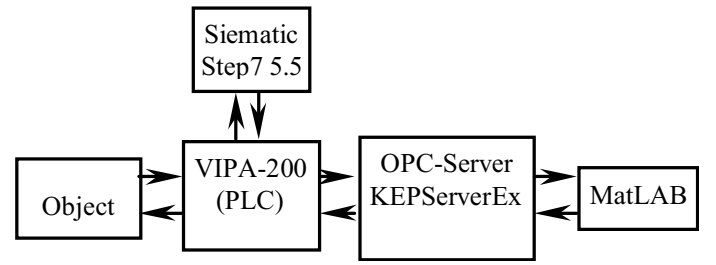

Fig. 3. Structure of the organization of information flows

Starting with version 6.5 MatLab integration interface in industrial automation standards has been developed. One is the OPC Toolbox, which comprises using Simulink model for data exchange. To do this, add a model OPC Configuration first communication interface. In the OPC Configuration power, speed and some other parameters are customizable. Next, the individual blocks are set parameters that are required to read and that must be changed. In contrast to the approaches inherent in software programs using Matlab processing of data is not tied to the types of data. Care should be taken to the choice of update rate due to the possible loss of transmission. It is important to set real-time using Real Time Windows Target Toolbox. This ensures a good flow time synchronization processes in the controller computer. The advantage of such modeling is its mathematical and physical clarity. Setting up the system is done through Simulink.

Intermediate OPC-server was used due to lack of opportunities in Matlab via MPI Data exchange from VIPA controller. At the physical level, the data was transmitted over the RS-232 protocol.

Direct reading of the input registers of the PLC is not possible. The controller program that introduces a separate function for the permanent transfer of values of the input registers is saved in retentive memory (marker).

\section{Static characteristic of the control object}

Its static characteristics were determined before carrying out research on the analysis of the dynamic properties of an object. A slow change in the control action when raising engine speed and reduce it has been implemented for this scheme.

Control Loop $\mathrm{f}-\theta_{\text {out }}$ (magnetic field engine speed output temperature) characterized by significant non-linearity (Fig. 4), which can be changed under the influence of the inlet temperature.

It should be noted that the Figure shows the perspective view of the static characteristic. It is obtained by averaging the values of a sequence of several experiments. The static characteristic is a clear direction of the hysteresis of temperature change, which is not reflected in the chart. A gained value may change under the influence of some

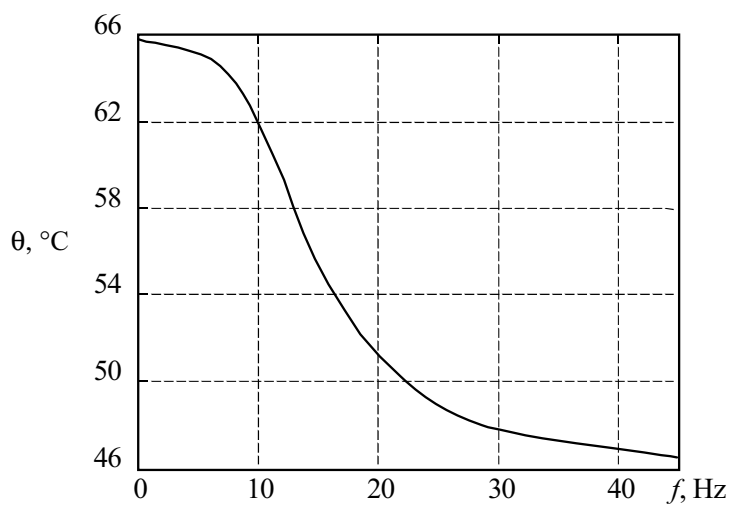

Fig. 4. Static characteristic of the object

factors. High sensitivity is observed from the change of the room temperature in which the installation is in into a non-thermostable room as we would like.

The number of people who were in the room for a long time was uncontrollable, it caused disturbances for the object and required a repetition of experiments to ensure the accuracy of the experiments.

\section{The dynamic characteristics of the control object}

All of the factors listed above affect not only the static characteristics, but also dynamic parameters. To minimize the influence of the disturbance factors, as mentioned above, follow the step sequence with the experiments. Experiments were carried out for several days. When selecting the time of the experiments we took into account weather conditions and the absence of sudden weather changes. Before starting the experiment, the output setting was on the stationary state and maintained without change control actions.

It should be noted that the form of the transient at the beginning of the day and when the output device at the first steady state after the heaters had a significant difference from the subsequent experiments. The first transient process consists of an aperiodic transient and a delay. When approximating aperiodic link curve of the second order with delay, the delay value obtained is about $10-20$ seconds. This is primarily due to the warming heaters and processing the main metallic element installation.

Temperature is a distributed parameter. Theoretical models of such objects usually give transfer functions of the form aperiodic link with delay. However, the experimental data (Fig. 4-8) are well approximated by an aperiodic link of the second order (3) (see Table 1).

$$
W=\frac{k_{0}}{\left(T_{1} p+1\right)\left(T_{2} p+1\right)} .
$$


Table 1. Results of the experiments

\begin{tabular}{|l|l|l|l|l|}
\hline № & $\mathrm{T} 1, \mathrm{~s}$ & $\mathrm{~T} 2, \mathrm{~s}$ & $\mathrm{k} 0,{ }^{\circ} \mathrm{C} / \mathrm{Hz}$ & Range, $\mathrm{Hz}$ \\
\hline 1 & 651.2 & 110.2 & $-0,9829$ & from 5.42 to 25.3 \\
\hline 2 & 583.2 & 82 & $-0,7811$ & from 25.3 to 12.7 \\
\hline 3 & 336.1 & 118.9 & $-0,6663$ & from 12.7 to 25.3 \\
\hline 4 & 533.5 & 336.1 & $-0,7487$ & from 25.3 to 12.7 \\
\hline 5 & 363.1 & 85 & -0.5117 & from 12.7 to 36.2 \\
\hline 6 & 613.5 & 162.7 & $-0,6877$ & from 36.2 to 12.7 \\
\hline
\end{tabular}

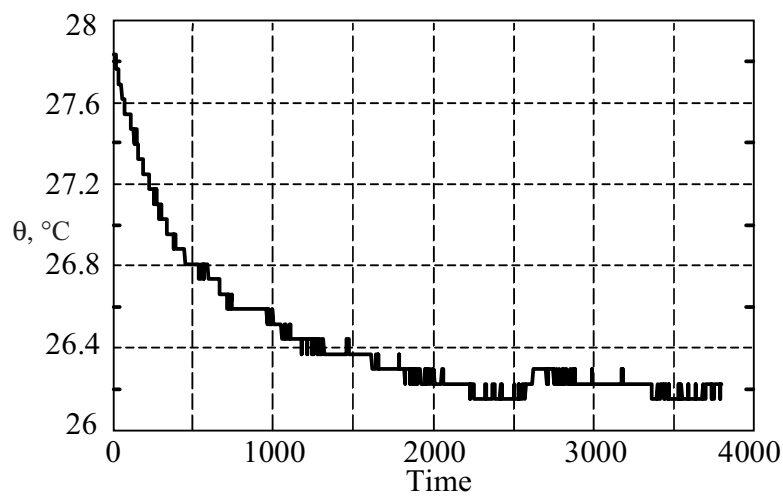

Fig. 5. The dynamics of the inlet temperature with change frequency $25.3 \mathrm{~Hz}$ to $5.42 \mathrm{~Hz}$

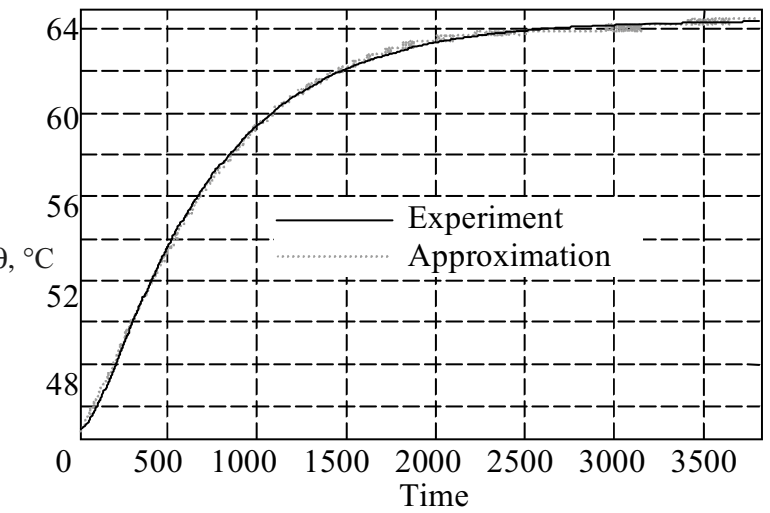

Fig. 6. The dynamics of the output temperature (a red line) with change $25.3 \mathrm{~Hz}$ to $5.42 \mathrm{~Hz}$ frequencies and its approximation (a black line)

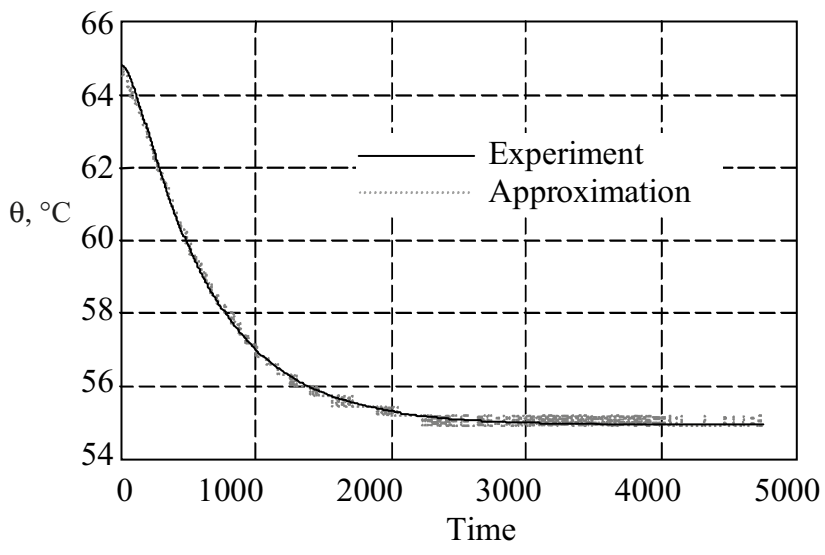

Fig. 7. The dynamics of the output temperature with change frequency $12.7 \mathrm{~Hz}$ to $25.3 \mathrm{~Hz}$ (a red line) and its approximation (a black line)

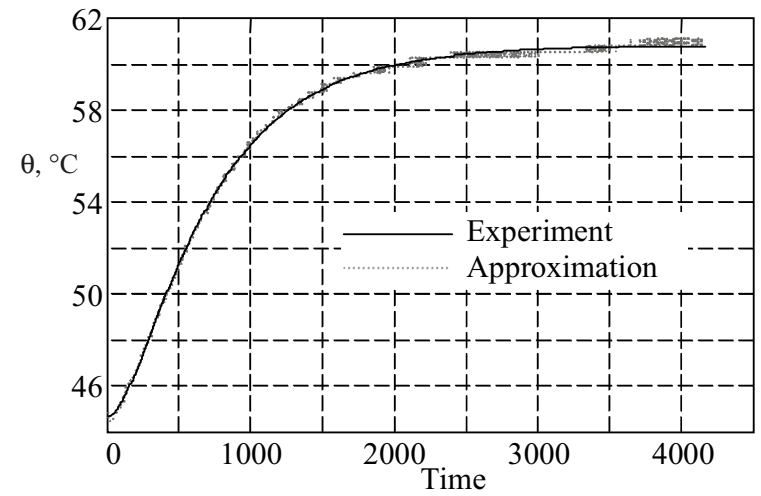

Fig. 8. The dynamics of the output temperature with change frequency 36.2 to 12.7 (a red line) and its approximation (a black line)

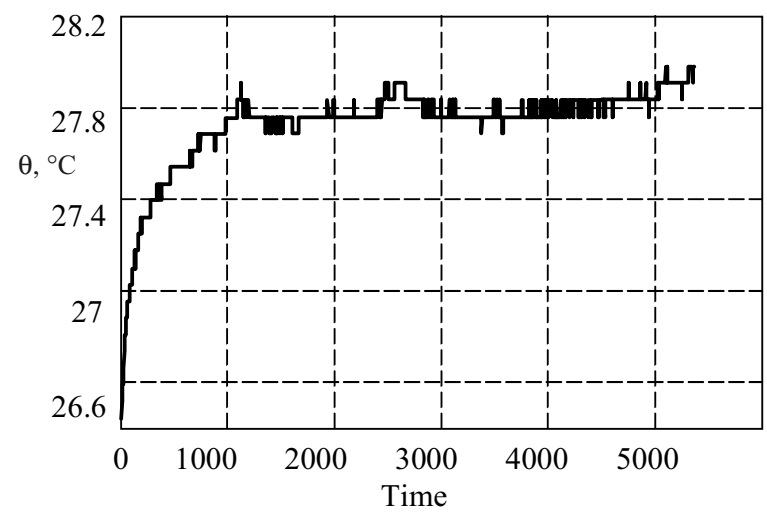

Fig. 9. The dynamics of input temperature (change frequency 12.7 to $36.2 \mathrm{~Hz}$ )

The parameters $T_{1}, T_{2}$ and $k_{0}$ are obtained by numerically minimizing standard deviation between the experimental data and the transition function for (3). The choice of the frequency range of the stepwise change for the study of the object was determined by the limit of the stable operation of the object.

Analysis of the results from Table 1 shows the presence of hysteresis for $T_{1}, T_{2}$ and $k_{0}$. When the fan speed increases, the system goes faster to a steady state value than when the fan is lowered.

Interesting behavior was observed in the inlet temperature sensor. It was installed between the engine and the heater. Since air was sucked in, heated and ejected in a single room, the temperature evolution was similar to the output temperature (room volume is approximately $150 \mathrm{~m}^{3}$ ). It differs only in the scope of fluctuations (Fig. 9).

\section{Conclusions}

The results of the study made it possible to determine the form of the transfer function of the control channel and the range of variation of its parameters. This will synthesize the PID controller with robust settings. The object has a 
significant hysteresis characteristic of the transmission coefficient and time constants.

\section{References}

Emerson Process Management. 2016. Advanced Control [online], [cited 30 November 2016]. Emerson Electric Co. Available from Internet: http://www2.emersonprocess.com/ en-us/brands/deltav/advanced/pages/index.aspx

Olson, G.; Piani, Dzh. 2001. Tsifrovyye sistemy avtomatizatsii i upravleniya. St. Petersburg: Nevsky Dialect, 2001. (In Russian)

VIPA products. 2016. Products [online], [cited 30 November 2016]. VIPA a Yaskawa Company. Available from Internet: http://www.vipa.co.uk/products/system-200v/cpus/

\section{EKSPERIMENTINIS ORO ŠILUMOKAIČIO DINAMIKOS VARIACIJOS TYRIMAS}

\section{Marozava, D. Hryniuk}

Santrauka

Valdymo sistemoms kurti skiriamas didelis dèmesys. Spendžiant technologinių procesų reguliavimo uždavinius kyla įvairių problemų. Viena iš tokių problemų yra valdymo kontūrų reguliavimas. Kai kuriems valdomiems objektams galimas vienkartinis valdymo kontūro suderinimas, kuris esant poreikiui periodiškai būtų reguliuojamas. Kituose objektuose pokyčiai tam tikrame diapazone vyksta labai greitai. Tokiu atveju pirmiausia reikia ivertinti pokyčiu diapazoną. Tada galima surasti universalius nustatymus, kurie užtikrins sistemos stabilumą ir stabilizavimo kokybę. Vienos iš tokių sistemu yra oro šilumokaičiai. Straipsnyje pristatomi oro šilumokaičio dinamikos sudarymo rezultatai. Nustatomos dinaminio modelio parametrų kitimo ribos. Valdymo kanalo perdavimo funkcijai būdingas žymus netiesiškumas.

Reikšminiai žodžiai: šilumokaitis, modelis, aktyvus eksperimentas. 